\title{
Was Karlstadt 'Insane' on Mosaic Law like Melanchthon said?
}

\begin{abstract}
Author:
Joel McDurmon ${ }^{1,2}$

Affiliations:

${ }^{1}$ American Vision, Inc.

Powder Spring, United States

${ }^{2}$ Faculty of Theology,

University of Pretoria,

South Africa

Note:

This research is based on a

PhD degree at the University

of Pretoria (2012) in

Systematic Theology under

the supervision of Prof. Dr

Johan Buitendag.

Correspondence to:

Joel McDurmon

Email:

jmcdurmon@gmail.com

Postal address:

3150A Florence Road,

Powder Springs, GA 31057,

United States

Dates:

Received: 29 Mar. 2012

Accepted: 14 June 2012

Published: 13 Sept. 2012

How to cite this article:

McDurmon, J., 2012, 'Was

Karlstadt "Insane" on Mosaic

Law like Melanchthon said?', HTS Teologiese Studies/

Theological Studies 68(1),

Art. \#1252, 6 pages. http://

dx.doi.org/10.4102/hts

v68i1.1252
\end{abstract}

C 2012. The Authors.

Licensee: AOSIS

OpenJournals. This work

is licensed under the

Creative Commons

Attribution License.
This article reviewed claims made by modern scholars Ford Lewis Battles and G.H. Williams, as well as charges made by Melanchthon, against Andreas Karlstadt (1486-1541) in regard to the imposition of Mosaic Law upon the civil realm. Melanchthon called Karlstadt 'insane' based on this charge, whilst Battles claims Karlstadt proposed to replace European civil law completely with the 'entire Mosaic code'. This study examined some of Karlstadt's writings in regard to images, the pace of reforms in Wittenberg, and the preference for reform to be carried out by the princes and not the masses. It also consulted the secondary source analyses of Ulrich Bubenheimer and Calvin Augustus Pater - both of which present views opposite to that of Battles, and both would have been available to Battles in 1986. The results of the literary review conducted in this study demonstrate that the claims of Battles, Williams, and Melanchthon are not supported by the evidence.

\section{Introduction}

In regard to the issue of Mosaic Law during the early Reformation, it is not uncommon to encounter the name of Andreas Karlstadt ${ }^{1}$ - the early colleague of Luther and Melanchthon. Some scholars even cite Karlstadt as a radical on the subject. Ford Lewis Battles, for example, states that Karlstadt 'had proposed literally substituting the entire Mosaic code of the Old Testament for the civil laws of European nations' (Battles 1986:lix).

Battles was not alone in his view. G.H. Williams considered Karlstadt alongside preachers Jacob Strauss and Wolfgang Stein with the claim, 'All these radical preachers ... held fiercely to the view that with the overturn of papal authority Mosaic law should obtain in Evangelical lands' (Williams 1957:47-8).

Karlstadt was openly accused of this offense by his own contemporaries. Melanchthon, in his 1531 Defense of the Augsburg Confession, called Karlstadt 'insane' for 'imposing upon us the judicial laws of Moses' (under Article 16, Political Order). Around the same time (1530-1531) he elsewhere complained about Karlstadt's allegedly mandatory view of Mosaic judicial code:

But some persons assign piety as a pretext to this case and deny that the laws of the Gentiles are to be used by the Christian. Therefore they try to pass new laws or call us back to the laws of Moses, as for example, Carlstadt, who very violently contended that, abandoning Roman laws, the laws of Moses were to be received. (Battles 1986:333)

It would seem just from this that Battles' claim has strong support. Melanchthon was, after all, Karlstadt's colleague and was close to Karlstadt. Melanchthon was certainly in a good position to know Karlstadt's views. But we must remember that Melanchthon in this case is a secondary source. As well, his statements must also be considered within their particular historical context. Melanchthon penned this particular accusation against Karlstadt in 1530 - eight to nine years after Karlstadt's earliest writings on the subject. This comes after nearly half a decade of polemics from Luther, the social upheaval of the Peasant War (1524-1525), political and economic pressures against Mosaic teachings, and a drama that led ultimately to exile for Karlstadt. During this period, Luther protested Karlstadt's views even more derisively than Melanchthon did or probably could have. Luther would characterise Karlstadt's view of Moses as 'new monkery' and 'legalism', deriding his followers in Orlamünde as 'Jewish saints' (Luther 1967:159, 163, 166).

So was Karlstadt as 'insane' as Melanchthon insisted? Did he really intend to replace European civil law with 'the entire Mosaic code' as Battles claimed? This study will review some of Karlstadt's positions on Mosaic Law to demonstrate that these claims are untenable.

\section{Karlstadt on images}

Part - though by no means all - of Karlstadt's scriptural justification for the magistrate to remove images derived from Moses. The references to Moses include both the lawgiver's injunction 1.The author employs the original spelling for 'Karlstadt' except where the name appears in citation of other sources as 'Carlstadt'. 
against idolatry and his commands to destroy the idols of Canaan. In his 1522 tract On the Removal of Images, Karlstadt engaged the rulers with duties for Christian magistrates. After the dedication, the first sentence of the tract begins with Moses: 'To have images in churches and houses of God is wrong and contrary to the First commandment, "You shall have no other Gods before me" [Ex. 20:3]' (Carlstadt 1995b:102). His followers would later hurl this verse at Luther in Orlamünde. In his opening justifications, however, Karlstadt also went outside of Moses to the Gospels: "'My house is a house of prayer and you have turned it into a den of murderers" [Mt. 21:13]' (Carlstadt 1995b:102). For the rest of the tract, he proceeds to quote and apply passages from various places in the historical books, the prophets, Gospels, Acts, and Paul, all forbidding idolatry and images.

After this exposition, Karlstadt moves to discuss the actual physical removal of the images, and this is perhaps where the real controversy lies (it was one thing to speak against images, but actual removal would constitute a serious affront to Rome). For scriptural support he cites Moses and the examples of the Hebrew Kings. In Deuteronomy 7:5, God had commanded them to destroy the heathen altars, smash their images, and burn their idols (Carlstadt 1995b:118). The Hebrew Kings who performed this task thoroughly, such as Hezekiah and Josiah, received praise from God. Those who did not, received condemnation, such as Manasseh and Ammon. According to Karlstadt (1995b), these obedient Hebrew kings provided direct examples for the German princes to follow:

Now if our authorities had accomplished the divine counsel and resolution by ordering the wicked and deceitful wooden blocks from our churches and consigning them to their deserved punishment, we would have to praise them, as the Holy Spirit praised Hezekiah ... Would to God that our lords were as the worldly, righteous kings and lords of Jewry, whom the Holy Spirit praised. According to Holy Scripture, they always have the power to take action in their churches and to put away everything that might annoy and hinder believers. They are also able to teach and lead priests to the laws of God and stop deceptive and harmful practices. (Carlstadt 1995b:118)

Just as Josiah ordered the priests and high priest to throw down the altars and vessels of Baal worship and burn them outside the city, so should modern kings purge the houses of God: 'We see from this that priests are subjects to Kings by divine right' (Carlstadt 1995b:118). This, of course, was not a Mosaic doctrine, but a confusion of jurisdictions on Karlstadt's account - (a confusion that Karlstadt's very antagonists, Luther and Melanchthon [as well as other reformers] would themselves engage in). Nevertheless, Karlstadt (1995b) continued:

On this account our magistrates should not wait until priests begin to carry out Baal's and their wooden vessels and obstructions. For they may never begin. The supreme temporal power must order and undertake action. (Carlstadt 1995b:118)

It was this type of 'must' to which Luther would, at that moment, so violently protest. In his view at the time, the entire Mosaic Law, including the Decalogue, was abrogated (though he would elsewhere argue the Decalogue was indeed part of natural law, and thus retained some usefulness). As we shall see in a moment, he would dismiss Karlstadt's first point coming from the First Commandment, and then proceed all the more strongly to denounce the idea that the judicial code of Moses in general bound Christian princes to action.

Whilst this was not exactly the point Karlstadt had argued, he nevertheless anticipated the objection, likely having heard it personally from Luther and others (the writings of Aquinas, from his university studies) many times before. He wrote, 'several admirers of images will say, "The old law prohibits images, but the new one does not. We follow the new and not the old law"' (Carlstadt 1995b:119). He responded that the new law instead subsumes and includes the old:

Christ verifies his teaching through Moses and the prophets. He says that he did not come to break the law but to fulfill it, [Mt. 5:17] ... Christ did not trespass on the smallest letter in Moses' law. Neither did he add or subtract anything from Moses. In short, Christ did not set aside anything which pleased God in the old law. Christ stood by the old law both in intent and in content. Anyone who can reconcile the two sayings, namely, Fide legem antiquamas and Fide vel gratia legem stabilimus - 'Faith supersedes the law' and 'Faith and grace strengthen the law,' understands Moses, the prophets, Christ, and Paul. (p. 119)

Karlstadt (Carlstadt 1995b) then addresses his critics by showing the social consequences of denouncing Moses, were they to carry it out consistently:

Dear chaps, you claim that the old law prohibits images. For this reason you will allow them in houses of God, considering such prohibition to be insignificant. Why then do you not also say that we are not obligated to honor father and mother, because the old law commands it? Further, murder, unchastity, stealing, and suchlike evil deeds which are prohibited in the same tablets of the law which prohibit images - with the prohibition of images being the first and foremost law, while prohibition of murder, unchastity, stealing, etc., are placed at the bottom as lesser and smaller. Why do you not say that we shall indulge in adultery, stealing, murder, and suchlike? Why not tolerate them in our churches because they have been prohibited in the old law? (p. 119)

Karlstadt then again reminds his readers that not only Moses but Christ and Paul also promoted the same view of law and the attack on images and idolatry. Christ showed this in answering the rich young ruler who asked what he must do to inherit eternal life: he directed the young ruler to the Mosaic Law. Karlstadt asked, 'why, in this case, should I not also lead you to the law of Moses?' (Carlstadt 1995b:119120). Isaiah and Jeremiah were both upheld as 'evangelical' prophets by his critics - yet both also prohibited images and supported their removal (1995b:120). Paul likewise decried idolatry and the pagans' images of gods ( $R m$ 1:23), and commanded his disciples to shun idolatry on more than one occasion (1 Cor 5:9, 8:4, 10:14) (1995b:107). In fact, 'Paul says that anyone who does these things will not be saved' (see 1 Cor 6:9-10; G1 5:21; Eph 5:5) (1995b:108). Karlstadt therefore concludes, 'Moses and Paul agree. And I have shown from the epistles of Paul that no one who honors images comes to God' (1995b:120). 
It is clear from this brief overview of Karlstadt's tract against images that his position indeed referenced Mosaic Law, most particularly the Decalogue, and also the Old Testament historical examples of kings who upheld the Decalogue. Yet he also based this doctrine on the words and injunctions of the Gospels and the letters of Paul.

\section{The pace of reform}

In 1524, Karlstadt wrote to a friend in Joachimstal concerning an issue over which he and Luther (and the princes) obviously disagreed: the haste of reform on the issue of removing images. Karlstadt desired to move more swiftly; his opponents retained images, et cetera, citing concern for the weaker brethren and 'brotherly love'. Karlstadt suspected this as 'an unchristian cover-up' (Carlstadt 1995c:251). His argument amounts to the case that 'brotherly love' must have some substantial basis, lest we risk making 'love' a phantasm. That basis, according to Karlstadt (1995c), must be Christ's commandments:

To say that one should make concessions to brotherly love means nothing, because it is not clear whether the sort of brotherly love is an unchristian cover-up, readily as evil and harmful as any of the little inventions of the pope ... Christ has cancelled and nullified all brotherly love if it stands over against his commandments or turns one even slightly away from God. (p. 251)

The commandments Karlstadt intended were, of course, the Law of Moses. Despite the argument between him and Luther having persisted for at least two years to this point, and Karlstadt having been expelled from Saxony at Luther's urging (which Luther denied), Karlstadt maintained his views. The common law ethic promoted by Luther and others left their laws inconsistent, Karlstadt (1995c) chided:

I am very much surprised by our rulers and those learned in Scripture who punish carnal adultery but leave spiritual adultery [idolatry and images] unpunished. Spiritual adultery they intend to conquer with their breath and wind, but they fend off carnal adultery with swords, iron, fire, and wheels ... Moses commands that idolatrous or spiritual adulterers are to be put to death just like carnal adulterers [Dt 13 \& 17]. (p. 255)

Not only Moses, however, but Paul also equated the two sins:

If they would only look to their Paul properly, they would surely find that Paul punishes those who are enslaved to idols no less severely than those who are enslaved to whores. (Carlstadt 1995c:255)

For Karlstadt, the inconsistency reflected the princes' and Luther's arbitrary whim that itself amounted to an idol: 'Yet it has to be right because they want it that way, and they defend their honor and beautiful image of themselves' (Carlstadt 1995c:255).

Karlstadt's critics referred to Exodus 23:29-30 in order to persuade him to take the removal of images slowly for the weak. This, after all, was how God told Moses to confront the gentiles:

I will not drive them out before you in a single year, that the land may not become desolate, and the beasts of the field become too numerous for you. I will drive them out before you little by little, until you become fruitful and take possession of the land.
Karlstadt responded that 'little by little' referred to driving out the gentile people, but the issue of the gentile people's idols presented a separate issue. He urged his critics to read a little further:

You shall make no covenant with them or with their gods. They [their gods] shall not live in your land, lest they make you sin against Me; for if you serve their gods, it will surely be a snare to you. (Ex 23:32-33)

The 'little by little' applied to the people, yes, Karlstadt argued, but God absolutely prohibited their idols to remain at all. The destruction of the pagan idols themselves should commence immediately:

So God commanded the Jews two kinds of expulsion: one was the expulsion of their enemies; the other, the removal of the gods and idols or images of the Gentiles. The first was to happen at leisure; the other, immediately and suddenly [Ex 23] ... Therefore, whenever they were able to do so and were in control, the Jews were to destroy the idols of the Gentiles and not allow them to remain. (Carlstadt 1995c:265)

\section{The princes not the people}

Karlstadt reiterated what he had argued before, that God upheld this standard for the Judges and the Hebrew kings. Christ had done the same when he wrecked the tables and drove the moneychangers from the temple (Carlstadt 1995c:266-267). This destruction of idols should, however, not entail an international crusade: 'God did not order the Jews to do it in the entire world, but only in places which they were to conquer and in which they were to rule' (1995c:267). This meant, however, that Christian rulers indeed ought to take action in the places they ruled:

Accordingly, the conclusion is that where Christians rule, they are not to look to any magistrate [Oberkeit], but are to strike out freely and of their own and throw down what is against God even without preaching. (Carlstadt 1995c:267; Pater 1984:88)

This was perhaps the most unfortunate sentence Karlstadt ever wrote in regard to civil law, for his opponents would misinterpret it to mean that the masses should ignore laws and magistrates with which they disagreed, and execute vigilantism at will. But Karlstadt expressly did not mean this. Pater (1984) explains:

This passage does not favor untrammeled violence. The axe smashes wood, not human beings, and in that crucial respect Karlstadt is much more peaceful than most magisterial reformers. Moreover, the axe is wielded 'where Christians rule.' Karlstadt encourages Christian magistrates to alter the old forms of worship even when other authorities do not condone this. He intends to accomplish this in Wittenberg through town council, when the elector opposes further reforms. (p. 88)

Thus, Karlstadt in principle called for these reforms to be done through the princes, not the masses. He also understood, as the other reformers would, that they could use the hierarchy of magistrates to the advantage of reform. Where one authority refused to advance reform, another body or ruler could pressure, protect, oppose or impose. When Frederick the Elector slowed action on promised liturgical reforms, Karlstadt prayed against his duplicity from the pulpit. But when lower magistrates halted their reforms four years later 
in Rothenberg, Karlstadt petitioned the emperor himself to impose. The point was, always look to the ruler willing to act according to Christian principles, whether higher or lower (Pater 1984:84-85). This very principle had saved Luther's life. After the Diet of Worms in 1521, Emperor Charles V declared Luther an outlaw. After his safe passage home, he would be subject to arrest or murder without consequence. It was the lesser magistrate Frederick the Elector who had Luther 'kidnapped' on his trip home. His captors, defying the highest magistrate of the land, hid the outlaw safely at Wartburg Castle. Karlstadt simply wished Luther and Frederick to show the same Christian courage in further matters of reform.

\section{Bubenheimer's review}

In a detailed study of Karlstadt's views on theology and law, legal scholar Ulrich Bubenheimer (1977) argues that Karlstadt's views on Mosaic Law do not support the views that Melanchthon attributed to him. Bubenheimer (1977) writes:

We must point out, however, that we can in no way assume with certainty that the views attributed by Melanchthon to Karlstadt regarding the secular law were actually representative of Karlstadt. From the position of the sources to a secure assertion there stand several problems in the way. ${ }^{2}$ (p. 247)

This conclusion, Bubenheimer demonstrates, rests on several issues arising from the original sources. The first issue pertains to the content of the original sources themselves. Bubenheimer flatly states: 'The demand to replace the Roman law with the Mosaic Law cannot be demonstrated in Karlstadt's own writings' (Bubenheimer 1977:247). ${ }^{3}$ Instead, the only contemporary attestation of this view to Karlstadt by name comes from the pen of Melanchthon. It is, thus unsubstantiated hearsay: 'we know of this alleged claim of Karlstadt's only second hand. It is furthermore joined with the name of Karlstadt in express terms only after 1530 by Melanchthon'4 (Bubenheimer 1977:247).

Furthermore, this lone second-hand reference comes at a suspicious juncture and thus has a propagandistic aura. The charge comes only:

after Karlstadt had left town in Saxony in the beginning of 1529, and the break between Wittenberg and Karlstadt was final. Under these circumstances, a polemical exaggeration of the opinions of Karlstadt on Melanchthon's part is not surprising. ${ }^{5}$ (Bubenheimer 1977:247)

Secondly, Karlstadt's 1522 argument against images references Mosaic Law only in regard to ceremonial, or

2.Wir müssen allerdings darauf hinweisen, daß keineswegs mit Sicherheit angenommen werden kann, daß die von Melanchthon Karlstadt zugeschriebenen Auffassungen hinsichtlich des weltlichen Rechts tatsächlich so von Karlstadt vertreten wurden

3.Die Forderung, das römische Recht durch das mosaische Recht zu ersetzen, läßt sich in Karlstadts eigenen Schriften nicht nachweisen.

4.Wir kennen diese angebliche Forderung Karlstadts nur aus zweiter Hand. Sie wird außerdem erst ab 1530 von Melanchthon expressis verbis mit dem Namen Karlstadts verbunden.

5.nachdem Karlstadt Sachsen Anfang 1529 verlassen hatte und der Bruch zwischen Wittenberg und Karlstadt endgültig war. Eine polemische Überzeichnung der Auffassungen Karlstadts von Seiten Melanchthons wäre unter diesen Umständen nicht verwunderlich. ecclesiastical aspects. His writings in this regard say little about his views of civil law: 'Whether that statement of Karlstadt's on the continued validity of the Mosaic Law applies also for the judicial law, from the writing on images here remains entirely open' (Bubenheimer 1977:247). ${ }^{6}$ Bubenheimer goes on to argue that Luther, in his own writings, engages the argument with Karlstadt in terms of Divine law in regard to the church, and thus confirms the view that Karlstadt had in mind ecclesiastical reform and not Mosaic revision of the common law of nations:

so it follows that Luther, while composing his book, clearly did not know of a radical demand of Karlstadt's for replacement of Roman law by the Mosaic. Had Karlstadt raised such a demand as Luther, in view of his polemical nature had imagined as generally reckoning with the 'fanatics,' he certainly would not have failed to turn this claim against Karlstadt. ${ }^{7}$ (Bubenheimer 1977:248)

Thirdly, Karlstadt presented no more radical a view of Mosaic Law than did Luther and Melanchthon themselves (Bubenheimer 1977:249). Indeed, in light of Melanchthon's and Luther's preferences for certain Mosaic Laws in civil polity, Karlstadt seems little more than a fellow traveller at best attempting to apply selective Mosaic Laws 'without trying thereby to displace the Roman law completely' (Bubenheimer 1977:249). ${ }^{8}$ It is certainly possible that Karlstadt tried to go further than the other two, but, 'in this regard, however, the sources let us down' (Bubenheimer 1977:250), ${ }^{9}$ especially considering that Saxony had banned all publications by Karlstadt during the relevant era, 1526-1529.

Fourthly, by the time Karlstadt is able to publish again in the 1530s, in Basel, he 'to a striking extent positively consults texts of Roman law in his writings' (Bubenheimer 1977:250). ${ }^{10}$ But during this same period in which he positively consulted Roman law texts in his writings, he maintained his former views against ecclesiastical law:

Although he, the doctor of laws, has given the canon law an uncompromising rejection, he has nevertheless maintained ties to the Roman law until the last phase of his work. (Bubenheimer $1977: 250)^{11}$

Based at least on these four reasons, Bubenheimer concludes that the sources do not support the claim that Karlstadt wished to impose Mosaic law as civil polity and replace the pagan civil laws of the land: 'that he ever wanted completely

6.0 ob jene Aussage Karlstadts über die Weitergeltung des mosaischen Gesetzes auch für die Judizialgesetze gelte, bleibt von der Bilderschrift her durchaus offen.

7. ... so ergibt sich, daß Luther bei Abfassung seiner Schrift von einer radikalen Forderung Karlstadts nach Ersatz des römischen Rechts durch das mosaische offenbar nichts bekannt war. Hätte Karlstadt eine solche Forderung erhoben so hätte Luther angesichts des polemischen Charakters seiner als Generalabrechnung mit den ,Schwärmern' gedachten Schrift sicher nicht versäumt, diese Forderung gegen Karlstadt zu kehren.

8.... ohne dadurch das römische Recht völlig verdrängen zu wollen.

9.Jedoch lassen uns die Quellen in dieser Hinsicht im Stich.

10.... wieder in auffallendem Umfang Texte des römischen Rechts in seinen Schriften positiv heranzieht.

11.Er, der Doktor beider Rechte, hat zwar dem kanonischen Recht eine kompromißlose Absage erteilt, Bindungen an das römische Recht hat er jedoch bis in die letzte Phase seines Wirkens festgehalten. 
to replace the Roman law with the Mosaic Law seems to me unlikely in any case for the reasons mentioned' (Bubenheimer 1977:250). ${ }^{12}$

It is worth noting here that Bubenheimer's monograph dedicated to the issue of Karlstadt and law was published in 1977. It had thus been available to Battles for at least nine years before the translation and publication of the 1536 Institutes (Battles 1986; Calvin 1986).

\section{What Karlstadt really said}

The truth about Karlstadt's view of law comes out a bit differently than the way Melanchthon and others have portrayed it. Far from 'legalism' or strictly instituting Mosaic Law:

Karlstadt is quite free in applying the laws of Moses, and he does so in a way that is much more progressive than the Sachsenspiegel, the law code of Saxony that meted out 'justice' according to one's standing in society. (Pater 1984:17)

Whilst he did argue for some changes in civil law, he nevertheless appealed (just as Calvin would later) for the equity of Old Testament principles and that this must be understood through New Testament concepts of mercy, including compassion toward unbelievers. Parts of the Old Testament are outdated and must yield to the New (Pater 1984:17), and the civil sword cannot serve to impose 'belief' or rid the land of other views. As early as 1520, Karlstadt had explained:

I do not want [unbelievers] to be killed that way, neither do I pray in the Judaic manner: 'May sinners perish from the earth, so they will be no more' - that is, may [they] be killed. Away, away, with that! Rather, let malice perish, let error be destroyed, and let the truth and knowledge of Christ replace error. (Pater 1984:17)

Karlstadt thus rejected the idea that magistrates could spread the kingdom of God with the sword and he rejected the idea of anything like holy war. In these instances again he 'links the Old Testament with the New, for opposition to unbelievers continues, but now with the sword of Scripture' (Pater 1984:17). In the end, Karlstadt 'always chooses the New Testament model for salvation' and 'harmonizes Old and New Testament in terms of the latter' (Pater 1984:17).

For Karlstadt, then, all of Scripture provides norms for good works and therefore direction for civil society. He made this point very clearly. Pater notes what we have already observed above in regard to the debate over images:

Christ did not subjugate anything that was pleasing to God under the old law. Christ remained within the will and the content of the old law. One who can add the following two sayings - 'by faith we overcome the law' and 'by faith or grace we establish the law' - understands Moses, the prophets, Christ, and Paul. (Pater 1984:18)

Further discrediting the idea that Karlstadt promoted a Moses-only view of civil law, he emphasises that some cases and matters exist which Scripture does not even touch upon. In these scenarios we must first consider what Scripture erscheint mir jedenfalls aus den genannten Gründen unwahrscheinlich. teaches, but realise that any decision or judgement made must, by the very uniqueness of its nature, expand upon those cases that are revealed:

God has widely undertaken to have us know through Holy Scripture what is pleasing in his sight and what displeases him. But there are certain faults and things which are not contained in Holy Scripture. Yet no one is to begin or do anything wantonly. We will have to give account of all our words and deeds and answer to whether or not we sought God's will in these, and sought it gladly.

Therefore, I do not mind seeing many Christian folk following the accounts of the apostles and not letting go or running away from it any more than they have to, but earnestly desiring to know God's will. And in cases where God did not sufficiently inform them, they would cast lots when through Holy Scripture they were not able to grasp and decide, like the apostles received Matthias by lot in place of Judas Iscariot, Acts 1, although the apostles could have been chosen according to Scripture. (Carlstadt 1995a:224; cf. Pater 1984:19)

Whilst Karlstadt hardly held views of separation of church and state comparable to Western civilisation in the twentyfirst century - none of the Reformers ultimately practiced anything like such a standard - 'nevertheless, Karlstadt does not unite the institutions of church and state, for they are seen as parallel entities with separate functions' (Pater 1984:80). Neither institution has absolute power over the other; each should check and reform the other when they go astray. Yet the issue of the limits of the institutional powers stands separately from the issue of the standard of law. What is important for this study is that when he does speak of imposing Christian values as civil law (whether we would judge this today as good or evil), he does not do so with sole recourse to the laws of Moses, let alone the entire Mosaic code.

Furthermore, Karlstadt argues for limited civil power. Christian rulers may not advance religion with the sword, for this deifies the State and makes it an idol:

[Hope in God] is one reason why the prophets often make the claim: 'I shall not place my hope on my bow. My sword will not make me blessed' [Ps 44:6]. 'You shall not put your confidence in princes' [Ps 118:9]. They do this because they do not wish to make a false god. They do not want to have an image in their hearts. They only want to confess him who cannot be depicted. For God does not permit it. (Pater 1984:83)

Rather, for Karlstadt, Christian rulers have a higher calling than that of religious executioners. They must act in Christ's mercy to offenders: 'Christ has ordered the rulers to search out in mercy those who have strayed, and bring them back' (Pater 1984:85).

Even when rulers act contrary to good religion or principle, Karlstadt does not find justification for revolt. We should respect and avoid confrontations with established rulers whenever possible (Pater 1984:85). We see this exemplified in Karlstadt's own letter to Frederick after the Elector moved to pull him from the pulpit:

I understand that you do not wish to keep me in the parish of Orlamünde. Thus I do not know a more submissive way to serve you than that I humbly defer to you and resign. (Pater 1984:85) 
Nor did he wish to receive a pension from the government which the regulations allowed, so he declined: 'Therefore I surrender to you and resign my archdeaconate and the rights I originally received with it' (Pater 1984:86). Karlstadt did remain in his pulpit unofficially by call of the congregation, but the State attempted to replace him with its own Statesanctioned preacher. Karlstadt and the congregation withstood the replacement on the grounds of separation between civil law and ecclesiastical affairs. Thus Karlstadt obeyed the magistrate, yet would resist the magistrate from overstepping his God-determined bounds - withstanding the civil ruler from interfering in ecclesiastical affairs (in this action he was more consistent than Luther and many of the other Reformers in general). Thus we see Karlstadt's view of the separation of powers: 'Government is to be obeyed even when it persecutes, but not when it requires a positive act against God's law' (Pater 1984:86).

Considering these substantial qualifications then, we can better understand Karlstadt's view of civil law. Granted, he did wish to consider Moses as a starting point, a standard, but he hardly limited civil law to Moses and even argued we should leave behind parts of Moses including many of the death penalties. Pater summarises Karlstadt's view as believing that the letter of the Mosaic law may have been surpassed, but the spirit may not be violated' (Pater 1984:8384.) Even this may be stretching the evidence. Again, we see from Karlstadt that his view of godly law involved the Bible in general and not just Moses or even Moses in particular. The standard is simply the Bible in general as opposed to worldly law: 'I call worldly law [weltlich gesetz ] [sic] all teaching that is not based on the Bible, yet wishes to serve God's honour, praise, or will' (Pater 1984:84).

\section{Conclusion}

Enough has been shown of how Karlstadt, despite receiving censure by name from Melanchthon, as well as Battles and Williams in the twentieth century, did not wish to replace the common law with Mosaic theocracy, did not look to Moses exclusively as a basis for civil law, certainly did not want to substitute 'the entire Mosaic code of the Old Testament for the civil laws of European nations' as Battles (1986:lix) claims, and in fact argued against instituting the totality of Moses' Law. We must therefore dismiss these charges against Karlstadt.

Melanchthon's particular charge of 'insanity', however, did not specify the wholesale replacement of European civil law with the entire Mosaic code. Melanchthon made this complaint against Karlstadt's only for allegedly 'imposing upon us the judicial laws of Moses' - a more general statement. Thus, to the extent that Karlstadt claimed that any of the Mosaic laws should apply to the civil realm of his day, we could regard him as fitting Melanchthon's description to the degree of such selective applications. To the same degree we could apply Melanchthon's charge of 'insane'. Nevertheless, in such a case, the same charge would apply to Luther, Melanchthon himself and most of the other magisterial reformers - and nearly everyone in the Reformed traditions since - for all of these have held that selective applications of Mosaic Law can apply to the civil realm in different ways and at different times. In this light, Melanchthon's charge seems more like a political tool to disenfranchise the influence of Karlstadt than a sincere theological opinion.

\section{Acknowledgements Competing interests}

The author declares that he has no financial or personal relationship(s) which may have inappropriately influenced him in writing this article.

\section{References}

Battles, F.L., 1986, 'Introduction,' in Institutes of the Christian Religion, 1536 ed. \& transl. F.L.Battles, Eerdmans and the H.H. Meeter Center for Calvin Studies, Grand Rapids, MI.

Bubenheimer, U., 1977, Consonantia Theologiae et lurisprudentiae: Andreas Bodenstein von Karlstadt als Theologe und Jurist zwischen Scholastik und Reformation, J.C.B. Mohr (Paul Siebeck), Tübingen.

Calvin, J., 1986, Institutes of the Christian Religion, 1536 Edition, transl. F.L. Battles, Eerdmans and the H.H. Meeter, Center for Calvin Studies, Grand Rapids, MI.

Carlstadt, A., von 1995a, 'The Manifold, Singular Will of God, The Nature of Sin', in E.J. Furcha (ed.), The Essential Carlstadt: Fifteen Tracts by Andreas Bodenstein, pp.
185-228, ed. H. Wayne Pipkin, Herald Press, Waterloo/ Ontario/ Scottdale, PA. 185-228, ed. H. Wayne Pipkin, Herald
(Classics of the Radical Reformation 8).

Carlstadt, A., von 1995b, 'On the Removal of Images and That there Should be no Beggars Among Christians', in E.J. Furcha (ed.). The Essential Carlstadt: Fifteen Tracts by Andreas Bodenstein, pp. 100-128, ed. H.W. Pipkin, Waterloo/Ontario/ Tracts by Andreas Bodenstein, pp. 100-128, ed. H.W. PI
Scottdale, PA. (Classics of the Radical Reformation 8).

Carlstadt, A., von 1995c, 'Whether We Should Go Slowly and Avoid Offending the Weak in Matters Pertaining to God's Will', in E.J. Furcha (ed.), The Essential Carlstadt: Fifteen Tracts by Andreas Bodenstein, pp. 247-268, ed. H.W. Pipkin, Herald Press, Fifteen Tracts by Andreas Bodenstein, pp. 247-268, ed. H.W. Pipkin, Herald
Waterloo/Ontario/Scottdale, PA. (Classics of the Radical Reformation 8).

Karlstadt see Carlstadt, A., von,

Luther, M., 1967, Against the Heavenly Prophets In the Matter of Images and Sacraments. Selected Writings of Martin Luther: 1523-1526, ed. T.G. Tappert, Fortress Press, Philadelphia, PA.

Melanchthon, 1969, 'Loci Communes', in W. Pauck (ed.), transl. W. Pauck \& L.J. Satre, Melanchthon and Bucer, pp. 18-152, The Westminster Press, Philadelphia, PA. (The Library of Christian Classics 19).

Pater, C.A., 1984, Karlstadt as the Father of the Baptist Movements: The Emergence of Lay Protestantism, The University of Toronto Press, Toronto.

Williams, G.H., 1957, 'Sermon Before the Princes: Introduction', in G.H. Williams (ed.) Spiritual and Anabaptist Writers, pp. 49-70, The Westminster Press, Philadelphia, PA. (The Library of Christian Classics vol. 25). 